\title{
Thermodynamic aspects of energetic utilisation of upgraded biogas in an IC engine
}

\author{
The paper presents the results of numerical modeling of an internal combustion engine fueled either with biogas \\ or upgraded biogas with taking into account the specific thermodynamic properties of the working fluid. \\ Key words: gas engine, engine cycle modelling, biogas, upgraded biogas, thermodynamic properties of the working fluid
}

\section{Termodynamiczne aspekty silnikowego wykorzystania biogazu uszlachetnionego}

\begin{abstract}
Artykut prezentuje wyniki modelowania numerycznego obiegu cieplnego tłokowego silnika spalinowego zasilanego alternatywnie biogazem lub biogazem uszlachetnionym uwzględniające specyficzne właściwości termodynamiczne czynnika roboczego.
\end{abstract}

Słowa kluczowe: silnik gazowy, modelowanie obiegu silnika, biogaz, biogaz uszlachetniony, właściwości termodynamiczne czynnika roboczego

\section{Introduction}

Directive 2009/28/EC of the European Parliament and of the Council of 23 April 2009 on the promotion of the use of energy from renewable sources [1] reaffirmed the Community's commitment to the Community-wide development of energy from renewable sources beyond 2010. Council supported the mandatory target of a $20 \%$ share of energy from renewable sources in overall Community energy consumption by 2020 and a mandatory $10 \%$ minimum target to be achieved by all Member States for the share of biofuels in transport petrol and diesel consumption by 2020 , to be introduced in a cost-effective way. Polish target (specified in Annex 1 National overall targets.....) is $15 \%$ share of energy from renewable sources in gross final consumption of energy in 2020.

Thereby the opinion formulated in the Commission communication of 10 January 2007 (Renewable Energy Roadmap), that a $20 \%$ target for the overall share (in overall Community energy consumption) of energy from renewable sources and a $10 \%$ target for energy from renewable sources in transport would be appropriate and achievable objectives, was fully supported.

Directive 2009/28/EC defines 'energy from renewable sources' (energy from renewable non-fossil sources), as wind, solar, aerothermal, geothermal, hydrothermal and ocean energy, hydropower, biomass, landfill gas, sewage treatment plant gas and biogases. Directive also defines 'renewable energy obligation' which means a national support scheme requiring energy producers to include a given proportion of energy from renewable sources in their production, requiring energy suppliers to include a given proportion of energy from renewable sources in their supply, or requiring energy consumers to include a given proportion of energy from renewable sources in their consumption.

\section{Renewable energy sources}

In accordance with Poland's energy policy until 2030 [10], accepted by the Council of Ministers on the $10^{\text {th }}$ of Oc-

\section{Wstęp}

Dyrektywa Parlamentu Europejskiego i Rady 2009/28/ WE z dnia 23 kwietnia 2009 r. w sprawie promowania stosowania energii ze źródeł odnawialnych [1] potwierdza zobowiązanie do rozwoju energii ze źródeł odnawialnych na terytorium Wspólnoty po roku 2010. Rada poparła obowiązkowy cel przewidujący $20 \%$ udział energii ze źródeł odnawialnych w całkowitym zużyciu energii we Wspólnocie do 2020 r. i obowiązkowy minimalny cel przewidujący $10 \%$ udział biopaliw w ogólnym zużyciu benzyny i oleju napędowego w transporcie, który wszystkie państwa członkowskie są zobowiązane osiągnąć do 2020 r. i który należy zrealizować w sposób efektywny pod względem kosztów. Cel Polski (określony w załączniku 1 do Dyrektywy) to $15 \%$ udział energii odnawialnej w roku 2020.

Tym samym podtrzymana została opinia (wyrażona w komunikacie Komisji z dnia 10.01. 2007), że $20 \%$ udział energii ze źródeł odnawialnych w całkowitym zużyciu energii (overall final consumption) i 10\% udział energii ze źródeł odnawialnych $\mathrm{w}$ transporcie są celami odpowiednimi i osiągalnymi.

W dyrektywie 2009/28 zdefiniowano także ,energię ze źródeł odnawialnych" (energię z odnawialnych źródeł niekonwencjonalnych niekopalnych) jako energię wiatru, energię promieniowania słonecznego, energię aerotermalną, geotermalną i hydrotermalną oraz energię oceanów, hydroenergię, energię pozyskiwaną z biomasy, gazu pochodzącego z wysypisk śmieci, oczyszczalni ścieków i ze źródeł biologicznych (biogaz) oraz ,obowiązek stosowania energii odnawialnej” oznaczający krajowy system wsparcia zobowiązujący producentów energii do wytwarzania części energii ze źródeł odnawialnych, obligujący dostawców energii do pokrywania części swoich dostaw przez energię ze źródeł odnawialnych (OZE) lub zobowiązujący użytkowników energii do pokrywania części swojego zapotrzebowania przez energię ze źródeł odnawialnych.

\section{Odnawialne źródła energii}

Zgodnie z przyjętą przez Radę Ministrów w dniu 10 listopada 2009 roku „Polityka energetyczna Polski do 2030 
tober 2009, nationwide energy consumption in the year 2020 must be of 4271 PJ and the $15 \%$ share of it corresponds to 641 PJ (complied with Poland's mandatory RES share). Figure 1 shows actual national primary energy consumption [5] and projected need for the final energy [10, Annex 2].

Defined in the Annex 2 of Poland's energy policy until 2030 market potential for the year 2020 (Table 1. Economic potential and possibilities for making the use of it - market potential of the renewable energy sources [10 annex 2]) is shown in the Fig. 2.

This potential (referring to the renewable resources for production of electric energy, network heat and transport fuels in Poland), in the year 2020 should reach

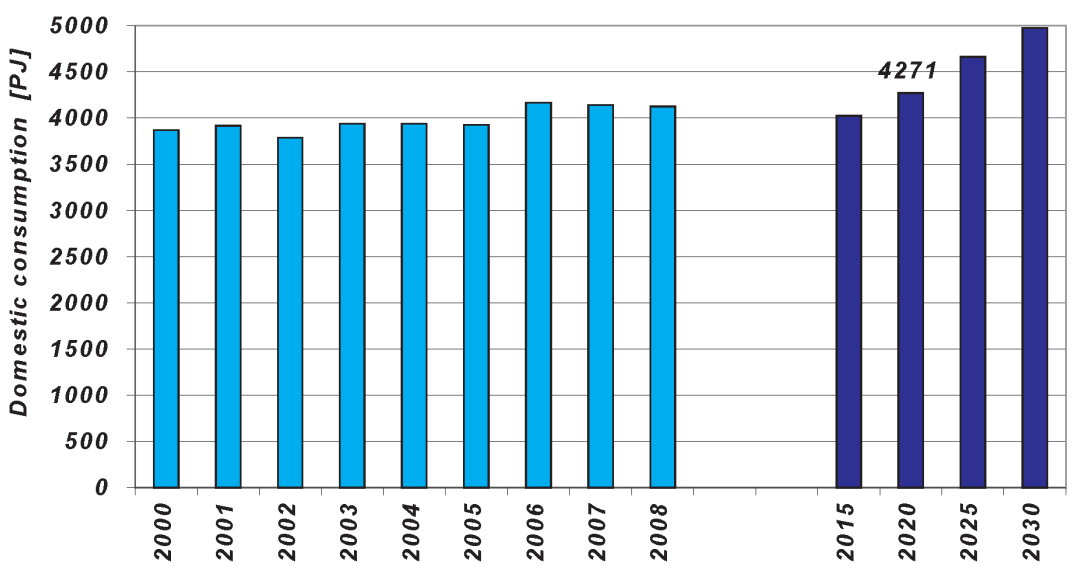

Fig. 1. Actual and projected final energy consumption in Poland Rys. 1. Dotychczasowe i przewidywane zużycie energii w Polsce 914 PJ (total) i.e. almost 1.5 times more then it comes of our country obligations (641 PJ). Estimated biogas potential alone exceeds 150 PJ. Aggregated potential of biofuels (bioethanol + biodiesel) is 63.5 PJ (i.e. more than $10 \%$ of actual consumption) $)^{1}$.

roku" [10] krajowe zużycie energii w roku 2020 winno wynosić 4271 PJ, a stąd 15\% udział (zgodnie ze zobowiązaniem Polski przypadający na OZE) to 641 PJ. Na rys. 1 pokazano dotychczasowe krajowe zużycie energii pierwotnej [5] oraz przewidywane zapotrzebowanie na energię finalną [10, zał. 2].

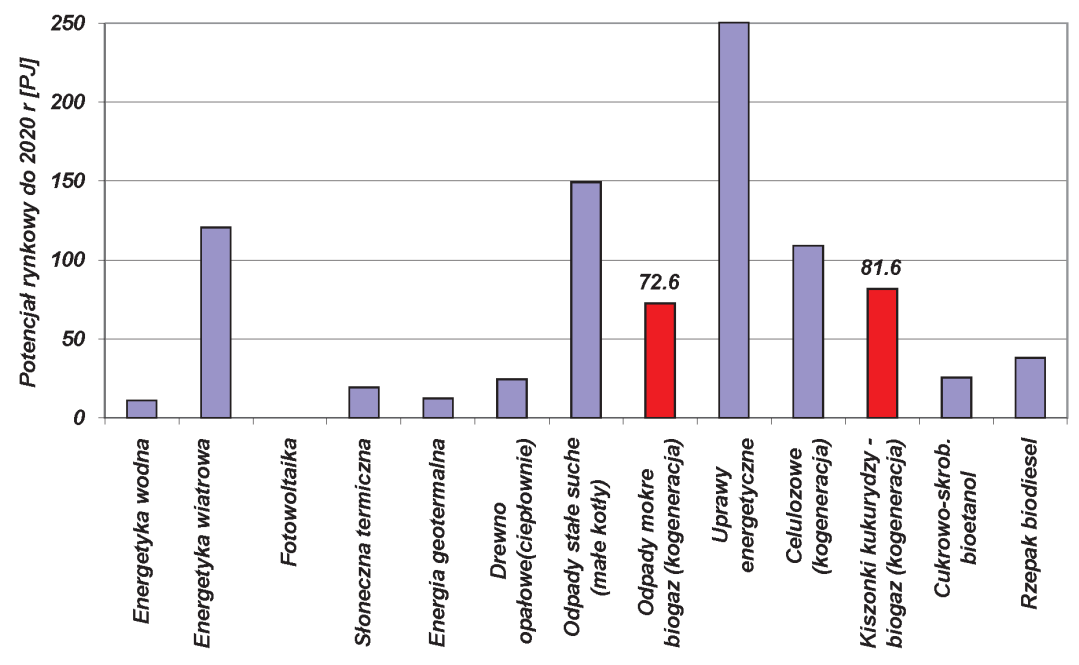

Określony w Załączniku 2 do „Polityki energetycznej Polski do 2030 roku" potencjał rynkowy na r. 2020 (Tabela 1. Potencjał ekonomiczny oraz możliwości jego wykorzystania - potencjał rynkowy odnawialnych zasobów energii [10, zał. 2]) został zilustrowany na rys. 2 .

Potencjał ten (odnoszący się do zasobów odnawialnych do produkcji energii elektrycznej, ciepła sieciowego i paliw transportowych w Polsce) to w $2020 \mathrm{r}$. (w sumie) ponad 914 PJ, a więc blisko 1,5 raza więcej niż wynika to ze zobowiązań naszego kraju (641 PJ). Same szacunki potencjału biogazu to ponad $150 \mathrm{PJ}$. Sumaryczny potencjał biopaliw (bioetanol+biodiesel) to 63,5 PJ (a więc ponad $10 \%$ aktualnego zużycia) ${ }^{1)}$.

Jeszcze większym „optymizmem Fig. 2. Energy market potential (projection to 2020) Rys. 2. Energetyczny potencjat rynkowy (projekcja na 2020)

biogazowym" charakteryzuje się program Innowacyjna Energetyka - Rolnictwo

Characterised by even bigger "biogas optimism" is $I n$ novative Energy Technology - Energy Agriculture (IERE) project [3], aiming to establish a system for promotion and support of agricultural biogas production and its use for electricity and heat production. The target is the annual biogas production (in the IERE project area), converted into pure biomethane ${ }^{2}$, of about 16 billion cubic meters (correspond-

\footnotetext{
1) According to the Panorama of Transport [9], Poland's energy consumption in transport was 13426 Mtoe i.e about 564 PJ (2006).

2) IERE project does not define the term ,,pure biomethane" but by proportion of annual production and primary energy follows it should be "pure methane" with LHV of $36 \mathrm{MJ} / \mathrm{m}^{3}$.
}

Energetyczne (IERE) [3], dążący do ustanowienia systemu promującego i wspierającego produkcję biogazu rolniczego oraz wykorzystanie go do produkcji energii elektrycznej i ciepła. Celem jest roczna produkcja biogazu (w obszarze IERE), wynosząca w przeliczeniu na czysty biometan ${ }^{2}$ około $16 \mathrm{mld} \mathrm{m}^{3}$ (jest to energia pierwotna w ilości ok. $160 \mathrm{TWh}$, więc $576 \mathrm{PJ}^{3}$ )). Program IERE zakłada budowę (do 2020 r.)

\footnotetext{
1) Wg Panoramy transportu [9] charakterystyczne dla Polski zużycie energii w transporcie wynosiło (w 2006 r.) 13426 Mtoe tj. ok. 564 PJ.

2) Program IERE nie definiuje pojęcia „,czystego biometanu”, ale z proporcji rocznej produkcji i energii pierwotnej wynika, iż chodzi tu o „czysty” metan o wartości opałowej $36 \mathrm{MJ} / \mathrm{m}^{3}$.

${ }^{3)}$ Byłoby to ponad $60 \%$ całych naszych zobowiązań
} 


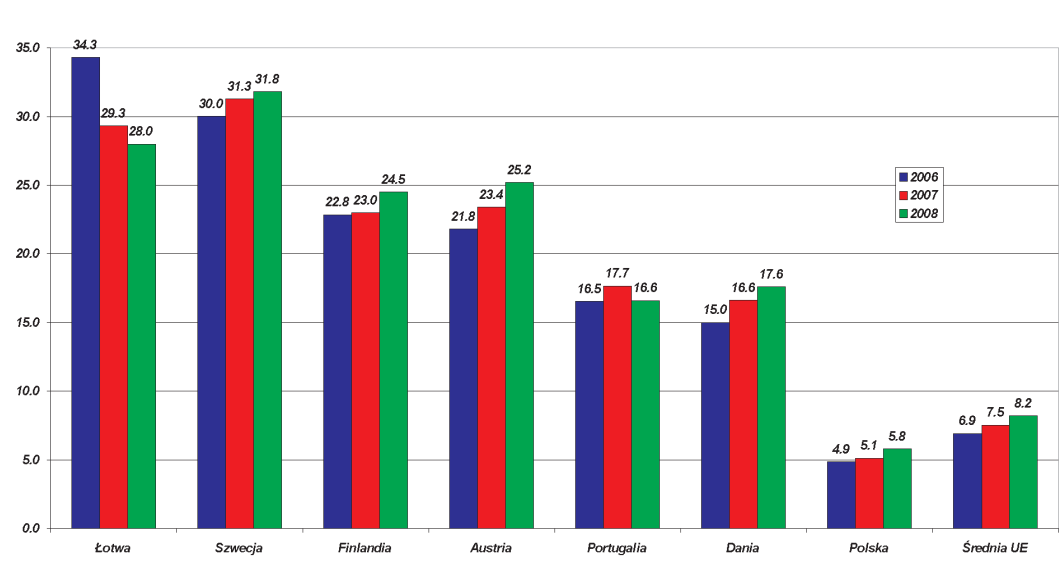

Fig. 3. Share of renewable energies in primary energy consumption of EU countries Rys. 3. Udzialy energii odnawialnej w krajach Unii

ing to primary energy of about $160 \mathrm{TWh}$, i.e. $\left.576 \mathrm{PJ}^{3)}\right)$. IERE scheme assumes the building (until 2020) of biogas plants, integrated with cogeneration sources, delivering combined electric power of about 5 thousand MW.

Current renewable energy shares were evaluated using the data from EurObservER's reports (years 2007-2009) [4] and collected in the Fig. 3.

The figure shows percentage share of renewable energy in primary energy consumption of leading (in this area) European countries (in 2008 Portugal "fell out" of the first five, replaced by Denmark), Poland and European Union's average. It indicates that Poland in the years 2006, 2007, 2008 occupied $16^{\text {th }}, 18^{\text {th }}$ or $15^{\text {th }}$ position respectively and the specific for our country ${ }^{4)}$ renewable energy shares were always below EU average.

In the light of forecasts (both governmental [10] and ministerial [3]) meeting the target of the energy policy i.e. $15 \%$ share of renewable energy in the structure of energy consumption in 2020, although probably possible, is no doubt a real challenge but - taking into consideration the present accomplishments (see p. 3) - serious acceleration of the development of all kinds of renewable energy sources, especially biomass (biogas) and wind energy, must follow.

\section{Biogas}

In the context of engine applications, the production of biogas is especially interesting. Polish National Energy Regulatory Office webpage hosts an interactive map presenting data for localizations of RES, their kind and power production capabilities (nation and countywide). The values (December 2009 data), collected in the Table 1, indicate that total power installed in Poland is about $2 \mathrm{GW}$, of which nearly half belongs to water plants (being basically energy accumulators) and biogas participates in about $4 \%$ of installed power. Significant position belongs to wind RES.

\footnotetext{
3) It would be more then $60 \%$ of our obligations.

4) Sources differ. In the GUS (Polish Central Statistical Office) case study Fuel-Energy Economy in the Years 2007, 2008 [5] renewables contribution to total energy consumption (after IEA) were 5.17\% (2006) and 5.13\% (2007). The Annex to the Directive 2009/28/EC states that this share was $7.2 \%$ in 2005 .
}

biogazowni zintegrowanych ze źródłami kogeneracyjnymi o łącznej mocy elektrycznej ok. 5 tys. MW.

Aktualne udziały energii odnawialnej określono w oparciu o dane zawarte w raportach EurObserv'ERa z lat 2007-2009 [4] i zebrano na rys. 3 .

Rysunek pokazuje procentowy udział energii odnawialnej w ogólnym zużyciu energii sześciu wiodących $\mathrm{w}$ tym zakresie państw europejskich (w r. 2008 Portugalia „wypadła” z pierwszej piątki, a jej miejsce zajęła Dania), Polski oraz średnią dla całej UE. Dowodzi, że Polska w latach 2006, 2007, 2008 zajmowała w Unii odpowiednio miejsce 16, 18 i 15, zaś charakterystyczne dla naszego kraju ${ }^{4)}$ udziały energii odnawialnej były zawsze poniżej średniej unijnej.

W świetle prognoz (zarówno rządowych [10] jak i resortowych [3]) spełnienie celu polityki energetycznej, w zakresie 15\% udziału energii odnawialnej w strukturze zużycia energii w 2020 r., choć być może wykonalne, jest niewątpliwie trudnym wyzwaniem i - biorąc pod uwagę dotychczasowe rezultaty (patrz p. 3) - musi nastąpić przyspieszenie rozwoju wykorzystania wszystkich rodzajów źródeł energii odnawialnej, a w szczególności energetyki biomasowej (biogazowej) i wiatrowej.

\section{Biogaz}

W kontekście zastosowań silnikowych szczególnie interesująca jest produkcja biogazu. Na stronie URE [8] znajduje się interaktywna mapa prezentująca dane o lokalizacji, rodzaju i mocy OZE (tak krajowe jak i powiatowe). Wartości (dane z grudnia 2009r.) zebrano w tablicy 1 wskazującej, że sumaryczna moc zainstalowana w Polsce to ok. 2 GW z czego blisko połowa to elektrownie wodne (będące w zasadzie akumulatorami energii), zaś biogaz (71 MW) partycypuje

Table 1. RES In Poland

Tabela 1. OZE w Polsce

\begin{tabular}{|l|c|c|c|}
\hline Source/źródto & $\begin{array}{c}\text { Number of installa- } \\
\text { tions/liczba instalacji }\end{array}$ & $\begin{array}{c}\text { Power/moc } \\
{[\mathrm{MW}]}\end{array}$ & $\begin{array}{c}\text { Share/ } \\
\text { udziat }\end{array}$ \\
\hline Biogas/biogaz & 125 & 70.89 & $3.56 \%$ \\
\hline Sun/słońce & 1 & 0.00 & $0.00 \%$ \\
\hline Water/woda & 724 & 945.21 & $47.42 \%$ \\
\hline $\begin{array}{l}\text { Biomass/bio- } \\
\text { masa }\end{array}$ & 15 & 252.49 & $12.67 \%$ \\
\hline Wind/wiatr & 301 & 724.66 & $36.36 \%$ \\
\hline $\begin{array}{l}\text { Co-combustion/ } \\
\text { wspótspalanie }\end{array}$ & 38 & 0.00 & $0.00 \%$ \\
\hline Total/razem & 1204 & 1993.244 & $100.00 \%$ \\
\hline
\end{tabular}

4) Źródła się różnią. W opracowaniu GUS ,Gospodarka paliwowo-energetyczna w latach 2007, 2008" [5] udziały energii odnawialnej w całkowitym zużyciu energii (za IEA) wynoszą odpowiednio 5,17\% (2006) oraz 5,13\% (2007) zaś w załączniku do Dyrektywy 2009/28/WE podaje się, że udział ten wynosił $7,2 \% \mathrm{w}$ roku 2005 . 
The report elaborated by the Institute of Fuels and Renewable Energy and Agency for Regional Development [11] includes list (Table 2) of electricity producing biogas installations. Besides them there is ca. 40 biogas installations producing only heat (mainly municipal biogas) and about 10 small privately owned agricultural biogas installations. It should be underlined that present capacity of agricultural biogas installations ( $7.25 \mathrm{MW}$ ) stands only for $0.15 \%$ of the IERE project forecasted capacity.

\section{Upgraded biogas}

Basic disadvantage (from the power producing point of view) of biogas is its small energy density at STP conditions (like the other gaseous fuels) which involves additional processes (compression, liquidation) that make the biogas, after proper treatment, suitable for the use in the gas pipeline grid or as a fuel for mechanical vehicles propelled by gas internal combustion engines.

Biogas is still more often subjected to the upgrading process, that aims to eliminate:

- carbon dioxide $\left(\mathrm{CO}_{2}\right)$

- hydrogen sulfide $\left(\mathrm{H}_{2} \mathrm{~S}\right)$

$-\operatorname{ammonia}\left(\mathrm{NH}_{3}\right)$

- water $\left(\mathrm{H}_{2} \mathrm{O}\right)$

- oxygen and nitrogen $\left(\mathrm{O}_{2}, \mathrm{~N}_{2}\right)$ (air)

- molecules of other substances.

There are four basic methods of biogas upgrading, based on the differentiation of the following properties of chemical species:

- adsorption (e.g. PSA - pressure swing adsorption)

- absorption (e.g. water scrubbing)

- permeation (e.g. membrane separation)

- cryogenic.

In Europe, pressure swing adsorption or water scrubbing are favoured [21]. In effect, biomethane is acquired, suitable both for the injection into the natural gas grid and automotive use, with no less than $95 \%$ of $\mathrm{CH}_{4}$ (Dutch requirements are satisfied with $80 \%$ ) [22]. It is characterised by Wobbe Index of $45 \mathrm{MJ} / \mathrm{m}^{3}$.

\section{Thermodynamic properties of biogas mixtures}

For the evaluation of the thermodynamic properties of the working fluid of internal combustion engine fuelled with biogas special spreadsheet was created (the polynomial NASA model [7, 16] was applied, illustrated in Fig. 4).

The transport properties - dynamic viscosity $(\eta)$ and heat conductivity $(\lambda)$ - are evaluated using the Lennard-Jones intermolecular potential model and Eucken's method. Properties of the gas mixtures are calculated by Wilke's empirical rule $[14,15]$ (enthalpy of chemical species is derived from NASA polynomials).

For the comparison two hypothetic fuels were taken: - biogas having $100 \% \mathrm{CH}_{4}$ content (upgraded biogas, LHV $=50 \mathrm{MJ} / \mathrm{kg}$ )

- biogas with equal (50\%) content of $\mathrm{CH}_{4}$ and $\mathrm{CO}_{2}$ (,,normal” biogas", LHV = 13.4 MJ/kg),

Two air-fuel mixtures were considered: stoichiometric and lean (air excess $\lambda=1.5$ ). Calculations were performed w ok. 4\% mocy zainstalowanej. Znaczącą pozycję zajmują wiatrowe OZE.

Raport opracowany przez Instytut Paliw i Energii Odnawialnej oraz Agencję Rozwoju Regionalnego [11] zawiera wykaz (tablica 2) instalacji biogazowych produkujących energię elektryczną ${ }^{5)}$. Prócz tego istnieje również ok. 40 instalacji biogazowych produkujących wyłącznie ciepło (głównie z gazu miejskiego) i około 10 małych instalacji rolniczych, posiadanych przez osoby prywatne. Należy podkreślić, iż aktualna moc rolniczych instalacji biogazowych (7.25 MW) to zaledwie $0,15 \%$ mocy prognozowanej $\mathrm{w}$ programie IERE.

Table 2. Biogas plants in Poland producing electricity and heat Tabela 2. Instalacje biogazowe $w$ Polsce stużace do produkcji elektryczności i ciepła

\begin{tabular}{|l|c|c|}
\hline Biogas plant/rodzaj instalacji & $\begin{array}{c}\text { Number of } \\
\text { plants/liczba } \\
\text { instalacji }\end{array}$ & $\begin{array}{c}\text { Installed po- } \\
\text { wer/dostepna } \\
\text { moc [MW] }\end{array}$ \\
\hline $\begin{array}{l}\text { Agricultural biogas plants/rolnicze } \\
\text { instalacje biogazowe }\end{array}$ & 6 & 7.25 \\
\hline $\begin{array}{l}\text { Sewage gas plants/instalacje } \\
\text { woczyszczalniach ścieków }\end{array}$ & 46 & 23.65 \\
\hline $\begin{array}{l}\text { Landfill gas plants/instalacje na } \\
\text { składowiskach odpadów }\end{array}$ & 73 & 39.99 \\
\hline Total/razem & 125 & 70.89 \\
\hline
\end{tabular}

\section{Biogaz uszlachetniony}

Podstawową wadą (z energetycznego punktu widzenia) biogazu jest jego niewielka gęstość energetyczna w warunkach normalnych (podobnie jak innych paliw gazowych) powodująca, że celowe są dodatkowe zabiegi (kompresja, upłynnianie) dzięki którym biogaz, poddany odpowiedniej obróbce, może zostać skierowany do sieci gazowej albo zostać użyty jako paliwo dla zasilania pojazdów mechanicznych napędzanych silnikami spalinowymi.

Biogaz jest coraz częściej poddawany uszlachetnianiu, którego celem jest eliminacja:

- dwutlenku węgla $\left(\mathrm{CO}_{2}\right)$,

- siarkowodoru $\left(\mathrm{H}_{2} \mathrm{~S}\right)$,

$-\operatorname{amoniaku}\left(\mathrm{NH}_{3}\right)$,

- wody $\left(\mathrm{H}_{2} \mathrm{O}\right)$,

- tlenu i azotu $\left(\mathrm{O}_{2} \mathrm{i} \mathrm{N}_{2}\right)$ (powietrze),

- cząsteczek innych substancji,

tak by uzyskać właściwości zbliżone do charakterystycznych dla gazu ziemnego.

Znane są cztery podstawowe metody uszlachetniania biogazu wykorzystujące zróżnicowanie właściwości:

- adsorpcyjnych (np. PSA - pressure swing adsorption),

- absorpcyjnych (np. płuczka wodna, water scrubbing),

- określających przepuszczalność (np. separacja membranowa),

- kriogenicznych.

${ }^{5)} \mathrm{W}$ chwili obecnej dobrze udokumentowane są tylko instalacje biogazowe produkujące elektryczność, które są zobligowane do uzyskania koncesji z URE oraz do składania corocznych raportów. 


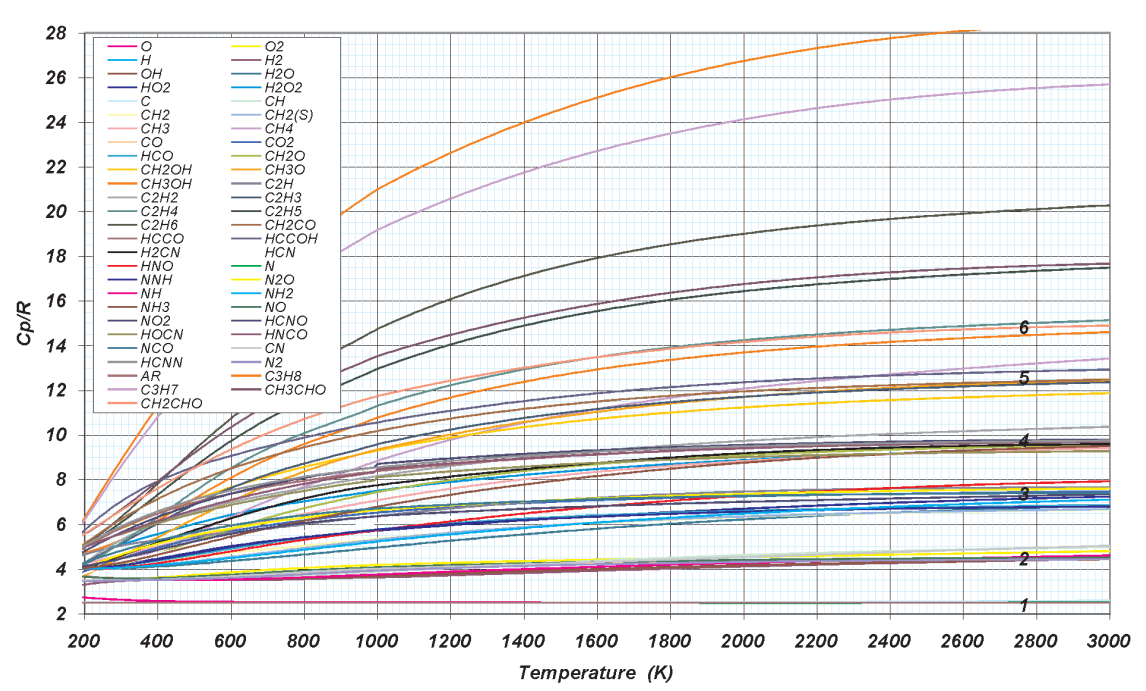

Fig. 4. Dimensionless specific heat of gaseous species

Rys. 4. Bezwymiarowe ciepło właściwe gazów

W Europie najchętniej stosuje się adsorpcję ciśnieniową (PSA) lub płuczki wodne [21]. W efekcie uzyskiwany jest biometan, nadający się zarówno do „wpuszczenia” do sieci krajowej jak i do zastosowania w pojazdach samochodowych, mający nie mniej niż 95\% $\mathrm{CH}_{4}$ (wymagania holenderskie przewidują 80\%) [22] i charakteryzujący się liczbą Wobbego na poziomie $45 \mathrm{MJ} / \mathrm{m}^{3}$.

\section{Termodynamiczne wlaściwości roztworów biogazowych}

Do oceny właściwości termofizycznych czynnika roboczego tłokowego silnika zasilanego biogazem przygotowano arkusz kalkulacyjny wykorzystujący do obliczeń ciepeł właściwych wielomiany NASA [7, 16], zilustrowane na rys. 4.

Obliczenia właściwości transporto-

for air with a relative humidity of $30 \%$ and residual gas fraction of ca. $5 \%$. The mass fractions of each component for the unburned and burned mixture (for $\lambda=1.5$ ) are presented in Fig. 5.

The results of the specific heat calculations (presented as specific heat ratio $\mathrm{C}_{\mathrm{p}} / \mathrm{C}_{\mathrm{v}}$ which is crucial for heat release rate), presented in Fig. 6, prove that there are no substantial differences between the properties of unburned and burned mixture and the leaning of the mixture involves the $1 \%$ drop in $\mathrm{C}_{\mathrm{p}} / \mathrm{C}_{\mathrm{v}}$ ratio (only slightly higher - ca. $2 \%$ - are differences in the fuel properties).
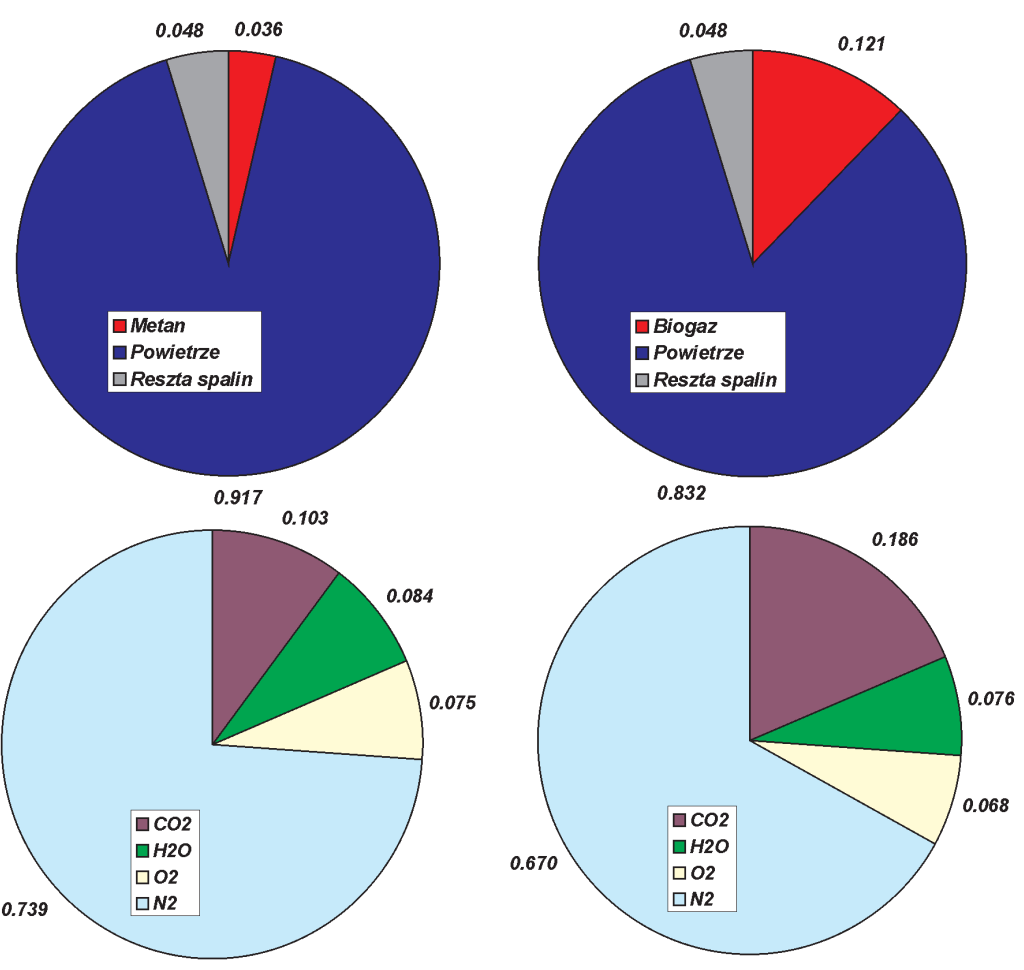

Fig. 5. Mass fractions of unburned and burned gas mixtures Rys. 5. Udziały masowe składników świeżego ładunku oraz spalin wych gazów (współczynniki lepkości dynamicznej $\eta$ oraz przewodzenia ciepła $\lambda$ ) prowadzono stosując potencjały Lennarda-Jonesa oraz zmodyfikowaną metodę Euckena. Właściwości roztworów obliczono wg reguły Wilkego [14, 15].

Do porównań przyjęto dwa hipotetyczne paliwa:

- biogaz o $100 \%$ zawartości $\mathrm{CH}_{4}$ (biogaz uszlachetniony) $\mathrm{i}$ wartości opałowej $50 \mathrm{MJ} / \mathrm{kg}$,

- biogaz o równej (50\%) zawartości $\mathrm{CH}_{4}$ i $\mathrm{CO}_{2}$ (biogaz „zwyczajny”, $\mathrm{W}_{\mathrm{d}}=13,4 \mathrm{MJ} / \mathrm{kg}$ )

oraz rozważono dwa rodzaje mieszanki palnej (stechiometryczną i zubożoną o $\lambda=1,5)$.

Obliczenia przeprowadzono dla powietrza o wilgotności wzgl. 30\% oraz współczynnika reszty spalin ok. 5\%. Udziały masowe poszczególnych składników świeżego ładunku oraz spalin (dla mieszanki o $\lambda=1,5$ ) pokazuje rysunek 5 .

Wyniki obliczeń ciepeł właściwych (w postaci ilorazu $\mathrm{C}_{\mathrm{p}} / \mathrm{C}_{\mathrm{v}}$, którego wartość decyduje o szybkości wydzielania ciepła), pokazane na rys. 6, dowodzą, iż nie ma znaczących różnic pomiędzy właściwościami ładunku przed i po spalaniu, a zubożenie mieszanki prowadzi do obniżenia $\mathrm{C}_{\mathrm{p}} / \mathrm{C}_{\mathrm{v}}$ o 1 procent (nieco większe - ok. $2 \%$ - są zmiany właściwości samego paliwa).

Kolejne rysunki prezentują lepkość dynamiczną (rys. 7 górny) oraz współczynnik przewodzenia (rys. 7 dolny) ładunku spalonego. Na rysunkach pokazano także aproksymacje, wyko- 


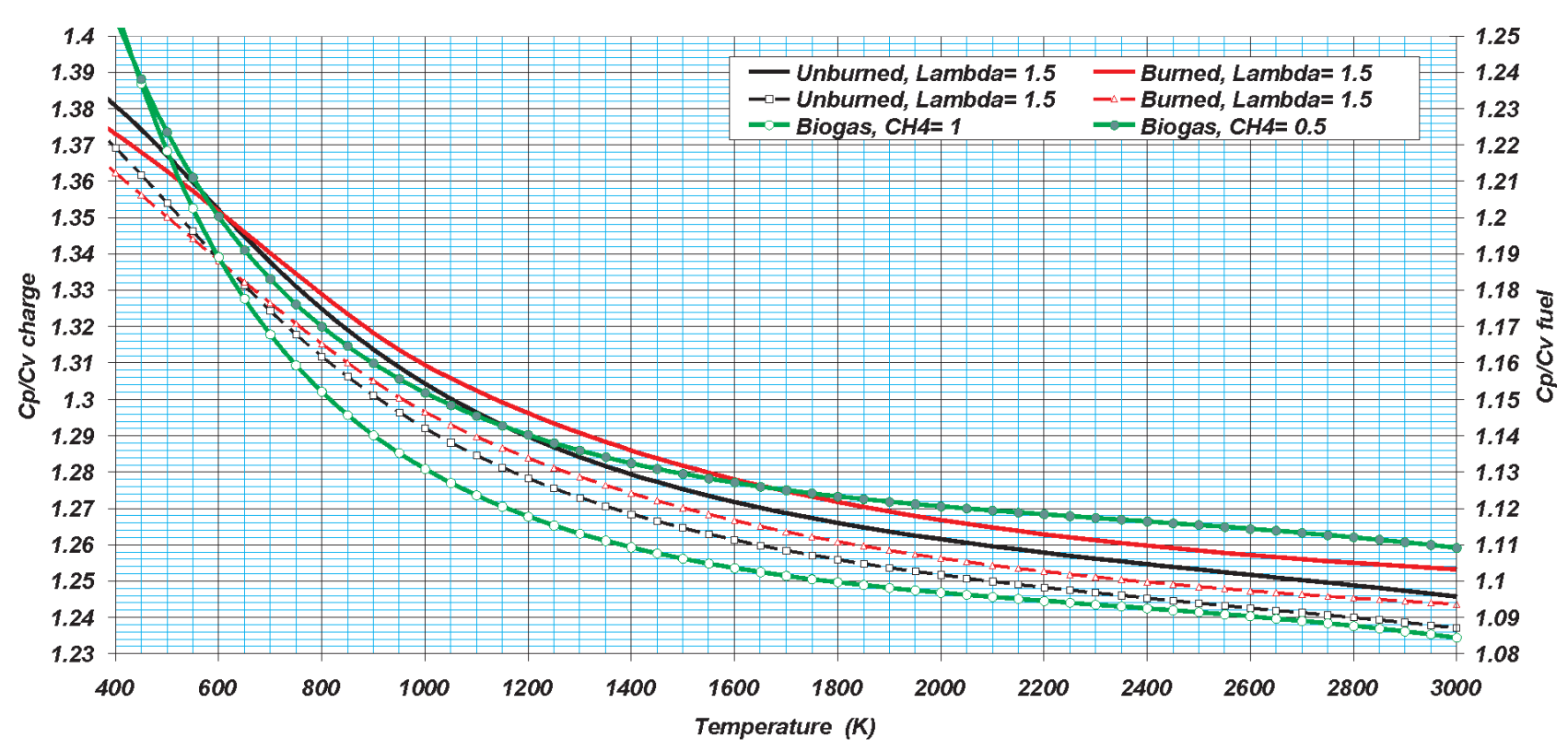

Fig. 6. Specific heat ratios for fuel, unburned and burned gas mixtures

Rys. 6. Ilorazy $C_{p} / C_{v}$ paliwa, tadunku niespalonego i ładunku spalonego

Subsequent figures present values of dynamic viscosity (Fig. 7, upper) and thermal conductivity (Fig. 7, lower) of burned gas mixture together with approximations used by G. Woschni $[12,13]$ for his calculations of the heat transfer
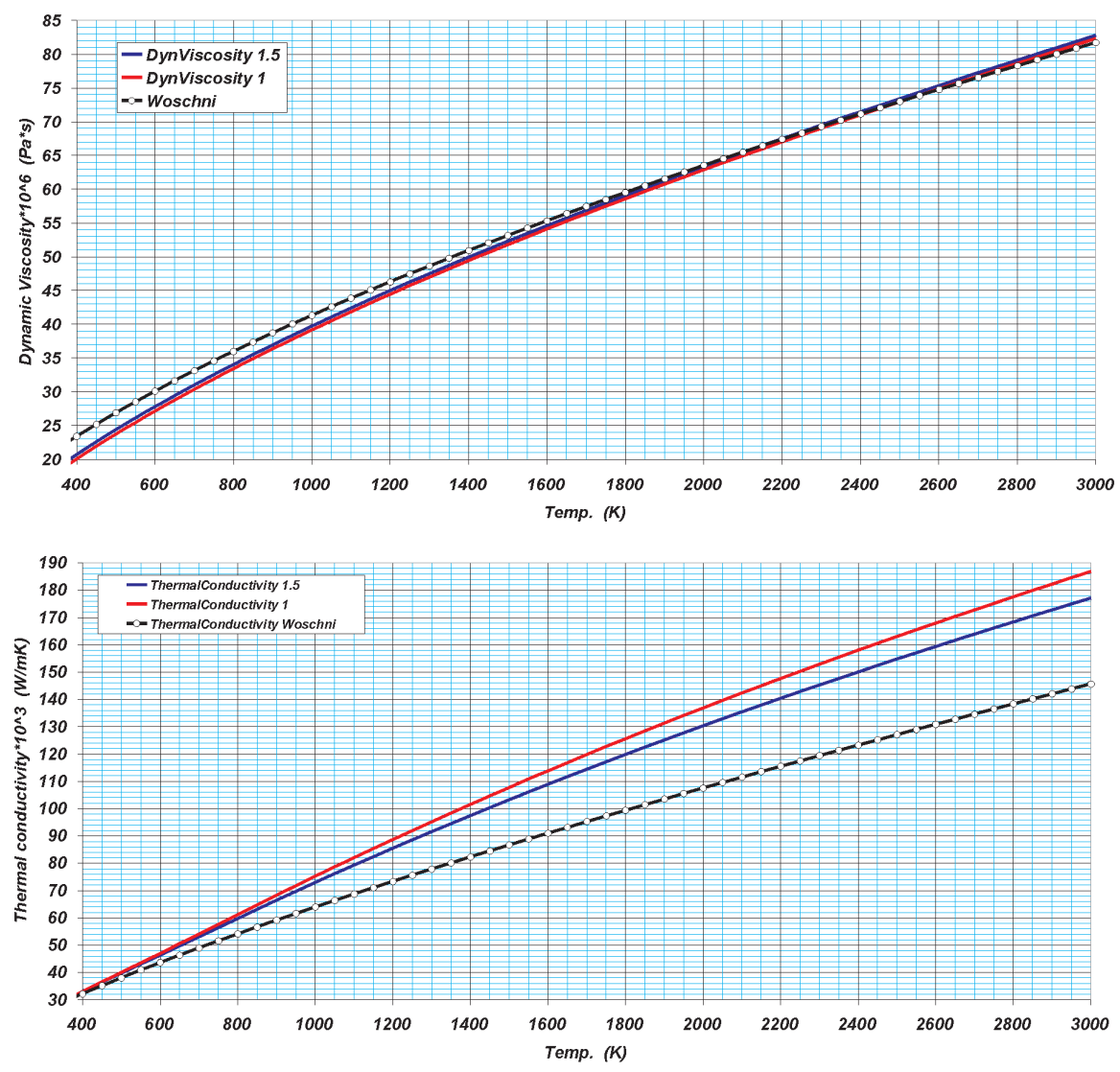

Fig. 7. Dynamic viscosity (upper figure) and thermal conductivity of working fluid Rys. 7. Współczynnik lepkości dynamicznej (rys. górny) i współczynnik przewodzenia ciepła czynnika roboczego rzystane przez G. Woschni [12, 13], do obliczeń współczynnika przejmowania ciepła. W przeciwieństwie do lepkości dynamicznej (rys. 7 górny - brak różnic), współczynnik przewodzenia (charakterystyczny dla spalania biogazu) wyraźnie odbiega od przyjętego przez Woschniego, szczególnie w zakresie wysokich temperatur, decydujących o wymianie ciepła (współczynnik przejmowania ciepła jest proporcjonalny do wyrażenia $\lambda / \eta^{0,8}$ ).

\section{Modelowanie obiegu silnika}

Ponieważ do oszacowania wpływu właściwości paliwa na osiągi silnika tłokowego niezbędne jest wprowadzanie zindywidualizowanych cech charakterystycznych czynnika roboczego (na co nie pozwalają programy komercyjne), przygotowano program modelujący (O-D) obieg 4-suwowego 1-cylindrowego wolnossącego silnika ZI o stopniu sprężania 9, w którym wykorzystano przedstawione wyżej obliczenia właściwości termodynamicznych. Założono, że obliczenia będą dotyczyć jedynie górnej pętli obiegu silnika tj. będą rozpoczynać się przy tych samych parametrach termodynamicznych czynnika roboczego, niezależnie od jego jakości.

Rezultaty tych obliczeń ilustruje rysunek 8, a w tablicy 3 zebrano wartości indykowanych wskaźników silnika dla różnych paliw (metan tj. 


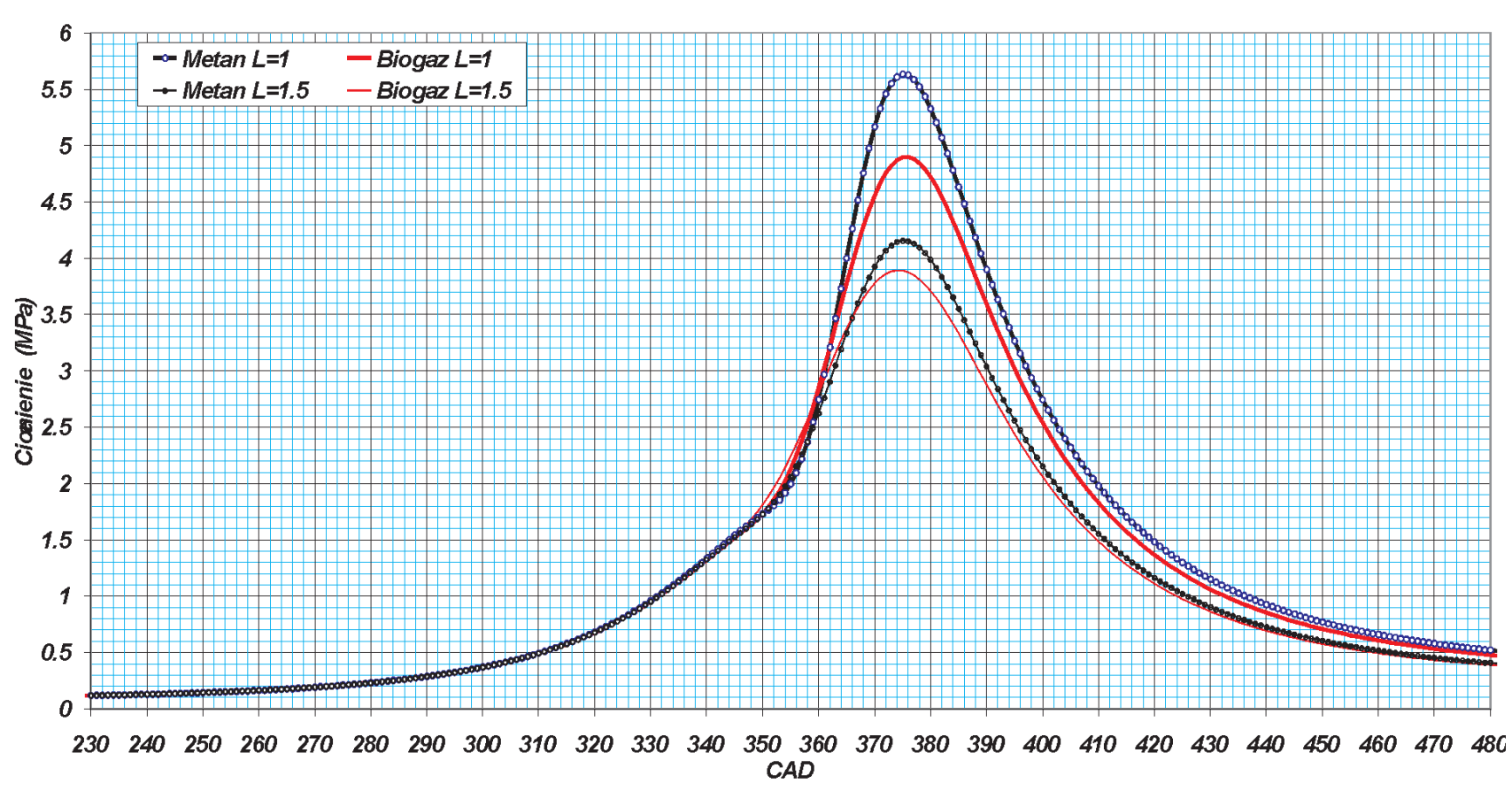

Fig. 8. Results of thermal cycle modelling

Rys. 8. Wyniki modelowania obiegu silnika

coefficient. On the contrary to dynamic viscosity approximations (upper figure shows negligible differences), the thermal conductivity coefficient (characteristic for biogas burned mixture) clearly differs from that applied by Woschni, especially in high temperature range, crucial for the heat transfer (heat transfer coefficient is proportional to the quotient of conductivity and viscosity $\left.\lambda / \eta^{0.8}\right)$.

\section{Engine cycle simulation}

For the evaluation the fuel properties influence on ICE performance it is substantial to take into account the composition and hence the specific thermodynamic properties of the combustion reactants and products. Since commercial codes do not allow for such intervention, special 0-D model was prepared for simulation of the thermodynamic cycle of 4-stroke 1-cylinder naturally aspirated spark ignition engine with compression ratio of 9:1. The presented above thermodynamic properties were applied in the calculations.

It was assumed that the modelling is limited to the upper loop of the engine cycle i.e. computations start at the same thermodynamic properties of the in-cylinder gas, regardless its combustion quality.

Numerical simulation results are illustrated in Fig. 8 while Table 3 presents the indicated values of engine parameters for various fuels (methane i.e. upgraded biogas and biogas with $50 \%$ content of $\mathrm{CH}_{4}$ and various air excess values $(\lambda=1$ and $\lambda=1.5)$.

Presented results indicate that the main feature of biogas upgrading is the possibility of IMEP improvement (by ca. $13 \%$ for $\lambda=1$ and $8 \%$ for $\lambda=1.5$ ) with moderate efficiency gain (3\% and $1.5 \%$ respectively). These results are similar to the experimental ones presented in the literature $[17,18$, $19,20]$. biogaz uszlachetniony oraz biogaz o $50 \%$ udziale $\mathrm{CO}_{2}$ ) i składów mieszanki $(\lambda=1$ oraz $\lambda=1,5)$.

Przedstawione wyniki dowodzą, że uszlachetnianie biogazu to przede wszystkim możliwość podwyższenia średniego ciśnienia indykowanego (o ok. 13\% dla $\lambda=1$ i $8 \%$ dla $\lambda=1,5)$ przy stosunkowo niewielkich wzrostach sprawności (odpowiednio 3\% i 1,5\%). Wyniki te są zbieżne z rezultatami badań eksperymentalnych $[17,18,19,20]$.

Należy pamiętać, że ,zwykły” biogaz ma także swoje specyficzne zalety: zawartość $\mathrm{CO}_{2}$ podnosi jego odporność przeciwstukową, a to umożliwia wykorzystywanie go w silnikach o wyższych stopniach sprężania.

Table 3. Indicated parameters

Tabela 3. Indykowane wskaźniki charakterystyczne

\begin{tabular}{|l|c|c|c|c|c|}
\hline Results/wyniki & & $\begin{array}{c}\text { Biogas/ } \\
\text { biogaz } \\
\lambda=1.5\end{array}$ & $\begin{array}{c}\text { Methane/ } \\
\text { metan } \\
\lambda=1.5\end{array}$ & $\begin{array}{c}\text { Biogas/ } \\
\text { biogaz } \\
\lambda=1\end{array}$ & $\begin{array}{c}\text { Methane/ } \\
\text { metan } \\
\lambda=1\end{array}$ \\
\hline $\begin{array}{l}\text { IMEP/średnie ciś- } \\
\text { nienie indykowane }\end{array}$ & $\mathrm{MPa}$ & 0.692 & 0.747 & 0.947 & 1.069 \\
\hline $\begin{array}{l}\text { Indicated thermal } \\
\text { efficiency/spraw- } \\
\text { ność indykowana }\end{array}$ & 0.389 & 0.395 & 0.377 & 0.389 \\
\hline $\begin{array}{l}\text { Max. pressure/ } \\
\text { ciśnienie maksy- } \\
\text { malne }\end{array}$ & $\mathrm{MPa}$ & 3.89 & 4.16 & 4.90 & 5.64 \\
\hline $\begin{array}{l}\text { Max. temperatu- } \\
\text { re/temperatura } \\
\text { maksymalna }\end{array}$ & $\mathrm{K}$ & 1928 & 2061 & 2444 & 2729 \\
\hline
\end{tabular}

Ewentualność ta została oszacowana w trakcie numerycznych badań porównawczych silnika:

- o stopniu sprężania 9, zasilanego biogazem uszlachetnionym, 
It must be kept in mind that "common biogas" has also its specific advantage: due to high $\mathrm{CO}_{2}$ content, weak biogas has high antiknock properties and that is why it may be utilized in high compression ratio IC engines.

That feature was evaluated during numerical comparison of two engines, characterized by:

$-\mathrm{CR}=9: 1$ and upgraded biogas fuelling

$-\mathrm{CR}=12: 1$ and weak $\left(50 \% \mathrm{CO}_{2}\right)$ biogas fuelling.

The results, illustrated in Fig. 9 and Table 4, indicate that proper use of this specific feature of common biogas may practically eliminate the efficiency differences between engines fuelled with biogas and upgraded biogas.

\section{Summary}

Presented in p. 2 plans of obligatory development of biogas installations, particularly the IERE (Innovative Energy Technology - Energy Agriculture) with its schedule of electric power installed in cogeneration sources integrated with biogas plants (50 MW - 2009, $150 \mathrm{MW}-2010,1000$ MW - 2013, $5000 \mathrm{MW}-2020$ ) bind us to consider the methods of optimal preparing and utilizing the biogas fuel. These methods should be effective from many points of view: energetic, economic (Directive 2009/28) and proper timing. The present degree of biogas installations development (current total power of $71 \mathrm{MW}$ ) does not offer the simple guarantee of realisation of the specified targets (71 MW corresponds to $1.4 \%$ of IERE plans for 2020 or $6 \%$ of the potential described in the Poland's energy policy until 2030.

The results of the numerical analysis taking into account the specific thermodynamic properties of engine working fluid may be summed up as follows:

1. First of all the upgraded biogas facilitate the increase in the power of gas engine and therefore should be used in
- o stopniu sprężania 12, zasilanego biogazem o 50\% udziale dwutlenku węgla.

Stosowne wyniki prezentuje rys. 9 oraz tablica 4 wskazując, iż wykorzystanie tej cechy zwykłego biogazu może praktycznie zniwelować różnice sprawności silników wykorzystujących biogaz i biogaz uszlachetniony.

Table 4. Indicated parameters (biogas engine has higher compression ratio)

Tabela 4. Indykowane wskaźniki charakterystyczne (silnik na biogaz ma podwyższony stopień sprężania)

\begin{tabular}{|l|l|c|c|c|c|}
\hline Results/wyniki & $\begin{array}{c}\text { Biogas/ } \\
\text { biogaz } \\
\lambda=1.5\end{array}$ & $\begin{array}{c}\text { Methane/ } \\
\text { metan } \\
\lambda=1.5\end{array}$ & $\begin{array}{c}\text { Biogas/ } \\
\text { biogaz } \\
\lambda=1\end{array}$ & $\begin{array}{c}\text { Methane/ } \\
\text { metan } \\
\lambda=1\end{array}$ \\
\hline $\begin{array}{l}\text { IMEP/średnie } \\
\text { ciśnienie indyko- } \\
\text { wane }\end{array}$ & $\mathrm{MPa}$ & 0.712 & 0.747 & 0.977 & 1.069 \\
\hline $\begin{array}{l}\text { Indicated ther- } \\
\text { mal efficiency/ } \\
\text { sprawność } \\
\text { indykowana }\end{array}$ & 0.399 & 0.395 & 0.387 & 0.389 \\
\hline
\end{tabular}

\section{Podsumowanie}

Przedstawione w p. 2 plany rozwoju (obligatoryjnego!) instalacji biogazowych, a w szczególności program IERE z jego ,harmonogramem instalowania mocy elektrycznej w źródłach kogeneracyjnych zintegrowanych z biogazowniami (50 MW - 2009, $150 \mathrm{MW}$ - 2010, $1000 \mathrm{MW}$ - 2013, 5000 MW - 2020)" każą zastanowić się nad sposobem przygotowania paliwa biogazowego tak, by było ono optymalne zarówno z energetycznego (zgodnie z Dyrektywą 2009/28), ekonomicznego jak i „czasowego” punktu widzenia. Obecny poziom rozwoju instalacji biogazowych (aktualna całkowita moc instalacji biogazowych to ok. 71MW) nie daje prostych gwarancji realizacji postawionych celów (to jedynie 1,4\%

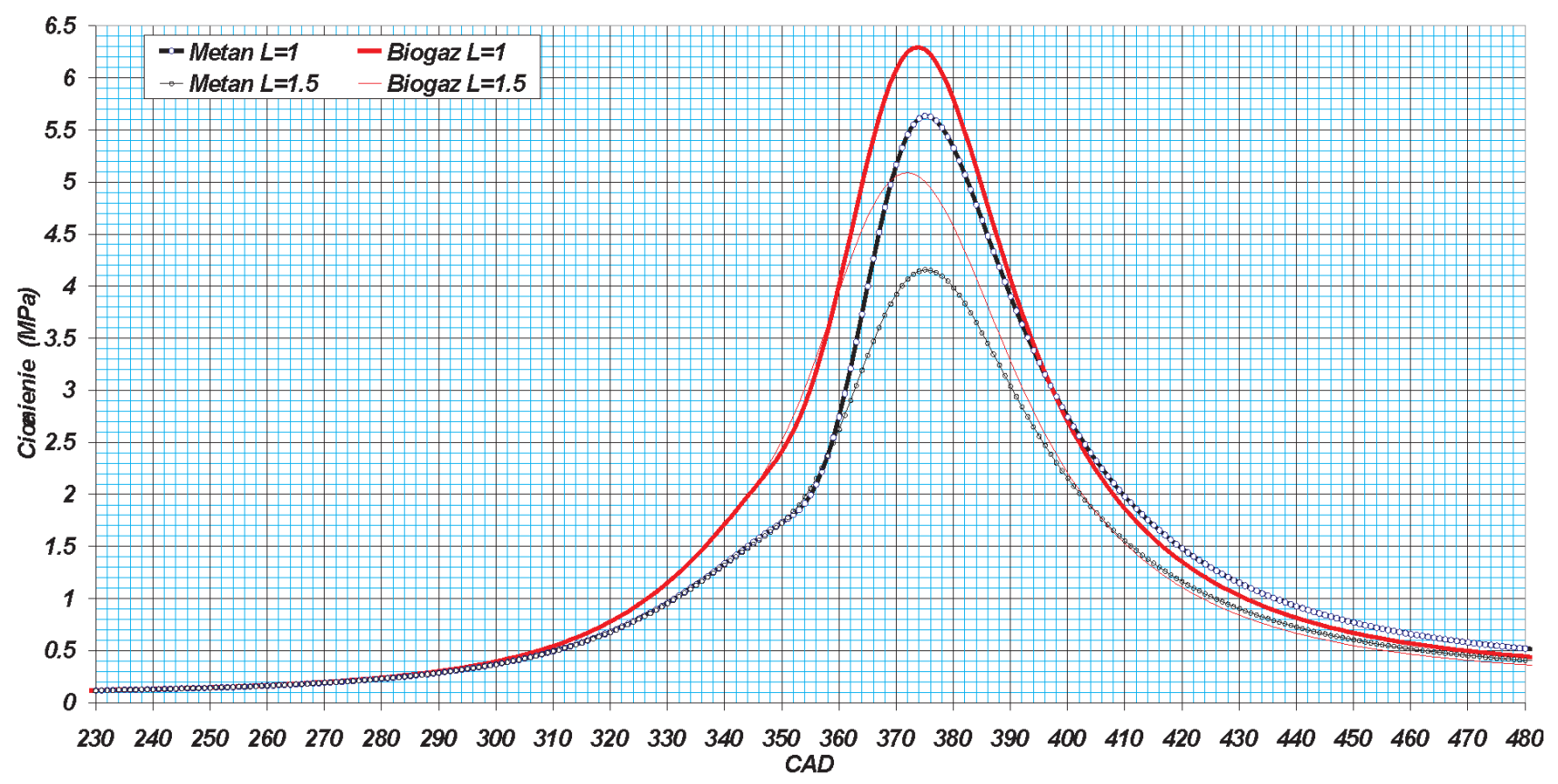

Fig. 9. Results of thermal cycle modeling (biogas engine has higher compression ratio) Rys. 9. Wyniki modelowania obiegu silnika (silnik na biogaz ma podwyższony stopień sprężania) 
vehicle engines (its high energy density makes it more attractive, but more expensive). There is necessity of the development of the infrastructure through local pipeline (at higher distance it may be expensive and difficult to realize from the logistic point of view) or the local natural gas distribution networks may be used. Automotive applications of upgraded biogas may require subsequent energy density enhancement;

2. The elimination of $\mathrm{CO}_{2}$ does not guarantee the IC engine efficiency improvement and may be futile for stationary distributed energy resource systems - it will increase the cost of the installation and be the reason of the longer realization period and lower return on investment in the comparison to cogeneration plant fuelled by „common” biogas from a fermentation.

Paper reviewed/Artykut recenzowany planów IERE na r. 2020 lub 6\% potencjału określonego w „Polityce energetycznej Polski do 2030 roku”).

Wyniki przedstawionych badań numerycznych, uwzględniających w modelowaniu obiegu silnika specyficzne właściwości termodynamiczne biogazowego czynnika roboczego, podsumować można następująco:

1. Uszlachetniony biogaz umożliwia przede wszystkim zwiększenie mocy silnika gazowego i jako taki winien być stosowany w silnikach trakcyjnych (ważna jest także jego wyższa gęstość energetyczna zmniejszająca koszty transportu paliwa, ale podwyższająca jego cenę). Konieczny jest rozwój infrastruktury poprzez specjalnie do tego celu zbudowany gazociąg (co przy większych odległościach może być drogie i trudne do realizacji z logistycznego punktu widzenia) lub też można wykorzystywać sieć przesyłową gazu ziemnego. Wykorzystanie takiego biogazu w pojazdach będzie wymagać dalszego podniesienia jego gęstości energetycznej;

2. Eliminacja $\mathrm{CO}_{2}$ nie gwarantuje wzrostu sprawności silnika i w przypadku stacjonarnej energetyki rozproszonej wydaje się być niecelowa - będzie podnosić koszta instalacji i wydłużać zarówno czas realizacji jak i zwrotu inwestycji w stosunku do zespołu kogeneracyjnego na ,zwykły” biogaz pochodzący z procesów fermentacyjnych.

\section{Bibliography/Literatura}

1. Dziennik Urzędowy Unii Europejskiej 5.6.2009 L 140/16 Pl: Dyrektywa Parlamentu Europejskiego i Rady 2009/28/WE z dnia 23 kwietnia 2009 r. w sprawie promowania stosowania energii ze źródeł odnawialnych.

2. http://www.iea.org/stats/balancetable.asp.

3. Program Innowacyjna Energetyka. Rolnictwo Energetyczne. http://egie.pl/files/IERE.pdf.

4. www.energies-renouvelables.org (Le baromètre EurObserv'ER 2007, 2008, 2009).

5. Gospodarka paliwowo-energetyczna w latach 2007, 2008. Główny Urząd Statystyczny, Warszawa 2009.

6. BIOGAS BAROMETER - JULY 2008. Le journal des énergies renouvelables $\mathrm{N}^{\circ} 186-2008$.

7. NASA Polynomials, www.me.berkeley.edu/gri_mech/data/ nasa_plnm.html.

8. http://ww.ure.gov.pl/uremapoze/mapa.html.

9. Panorama of Transport. Statistical Books Office for Official Publications of the European Communities, 2009, ISSN 18313280 .

10. Ministerstwo Gospodarki: Polityka energetyczna Polski do 2030 roku.

Prof. Krzysztof Z. Mendera, DSc., DEng., - Professor in the Faculty of Mechanical Engineering and Computer Science at Częstochowa University of Technology.

Dr hab. inż. Krzysztof Z. Mendera - profesor nadzwyczajny na Wydziale Inżynierii Mechanicznej i Informatyki Politechniki Częstochowskiej.

e-mail:mendera@imc.pcz.czest.pl
11. National Report on current status of biogas production - Poland. Instytut Paliw i Energii Odnawialnej Agencja Rozwoju Regionalnego. www.ipieo.pl www.arssa.pl.

12. Woschni G.: A universally applicable equation for the instantaneous heat transfer coefficient in the internal combustion engine. SAE 670931.

13. Woschni G.: Beitrag zum Problem des Wärmeüberganges im Verbrennungsmotor. MTZ 26/4, 1965.

14. Poling B.E., Prausnitz J. M., O’Connell J. P.: The properties of gases and liquids. McGraw-Hill Book Company USA 2001.

15. Mendera K.Z., Spyra A., Smereka M.: Analiza równania Woschni. VI Międzynarodowa konferencja naukowa silniki gazowe 2003 konstrukcja - badania - eksploatacja - paliwa odnawialne, 2003.

16. Mendera K. Z.: Thermodynamic properties of internal combustion engine working fluid. Journal of Kones Internal Combustion Engines, Vol. 9, 2004.

17. Roubaud A., Favrat D.: Improving performances of a lean burn cogeneration biogas engine equipped with combustion prechambers. Fuel 84 (2005), 2001-2007.

18. Porpatham E., Ramesh A., Nagalingam B.: Investigation on the effect of concentration of methane in biogas when used as a fuel for a spark ignition engine. Fuel 87 (2008) 1651-1659.

19. Jingdang Huang, Crookes R.J.: Assessment of simulated biogas as a fuel for the spark ignition engine. Fuel Vol. 77, No. 15, pp. 1793-1801, 1998.

20. Crookes R.J.: Comparative bio-fuel performance in internal combustion engines. Biomass and Bioenergy 30 (2006), 461-468.

21. Lechwacka M.: Uszlachetnianie biogazu do jakości gazu ziemnego. POLEKO 2009.

22. Petersson A., Wellinger A.: Biogas upgrading technologies developments and innovations. IEA Bioenergy, 2009. 